\title{
Original
}

\section{The Effect of High Glucose on Proliferation and Expression of Correlation Factors of MG63 Osteoblasts}

\author{
Zhou Linxi' ${ }^{1)}$, Zhang Guirong ${ }^{2)}$, Wang $\mathrm{Xue}^{2)}$ and Shen Gang ${ }^{1)}$ \\ 1) Department of Orthodontics, Shanghai Ninth Peoples Hospital, Shanghai Jiaotong University, Shanghai, China \\ 2) Department of Orthodontics, Stomatology Hospital of Shenyang, Shenyang, China \\ (Accepted for publication, February 4, 2015)
}

\begin{abstract}
The influence of high glucose on proliferation and expression of correlation factors including TNF related apoptosis inducing ligand (TRAIL), osteoprotegerin (OPG) and osteoprotegerin ligand (OPGL) of MG63 osteoblasts was detected in the present study. The relationship between the high concentration blood glucose and the physiological functions of human osteoblasts was studied. Then the pathogenesis of diabetes mellitus with chronic periodontitis was discussed. MG63 cells were cultured in different concentrations $(5.5 \mathrm{mmol} / 1,8$ $\mathrm{mmol} / 1,11 \mathrm{mmol} / 1,20 \mathrm{mmol} / 1,30 \mathrm{mmol} / \mathrm{l})$ medium for 24 hours. Cell proliferation was detected by MTT measurement. Flow cytometry was used to detect cell cycles. The mRNA expressions of TRAIL, OPG, and OPGL were detected by reverse transcription polymerase chain reaction (RT-PCR). The results showed that a low concentration of glucose has no significant influence on the proliferation of MG63 cells and other biological activity. With the increase of glucose concentration, the proliferation of MG63 cells was inhibited. The percentage of G1 phase cells was increased, the proportion of S phase kept unchanged and the percentage of G2 phase cells was decreased. With the increase of glucose concentration, the mRNA expressions of TRAIL and OPGL of MG63 cells showed an increasing trend while OPG showed an opposite trend. In conclusion, high glucose can inhibit the proliferation of MG63 and lead to the increasing mRNA expression of TRAIL and OPGL of human osteoblasts. However, the mRNA expression of OPG of human osteoblasts was decreased.
\end{abstract}

Key words: High glucose, MG63 cell, Cell cycle; Tumor necrosis factor

\section{Introduction}

High blood glucose concentration is harmful to many types of human cells, which causes many diseases, such as diabetes mellitus, stress and systemic inflammatory response after injury or operation ${ }^{1}$. Diabetes mellitus interact with various oral diseases. The abnormal blood glucose could cause periodontal, mucosal, endodontical and gland diseases of maxillofacial region ${ }^{2}$. Effective control of glucose metabolism for diabetes mellitus patients is helpful to improve the periodontal inflammation and maintain periodontal health ${ }^{3}$. It is known to all, diabetes mellitus patients are likely to develop osteoporosis ${ }^{4}$. The alveolar bone is one of the most active parts of the human skeleton. The reconstruction of the alveolar bone is a complex physiological process controlled by the external signal, system hormone level and local factors. Alveolar bone resorption is the pathological change of bone reconstruction disorders caused by periodontosis, osteoporosis or orthodontics accidentally ${ }^{5}$. These clinical issues affect people's oral health seriously. The present study is to detect the effect of

Corresponding to: Dr. Shen Gang, Department of Orthodontics, Shanghai Ninth People,s Hospital, Shanghai Jiaotong University, Shanghai 200011, China; Tel: +86 2123271699 , Fax +86 21 63131298; E-mail: 407526908@qq.com high glucose on the cell proliferation and cycle, the changes of TRAIL, OPG and OPGL expression. The high glucose concentration effect on the physiological function of human osteoblast was also determined. The pathogenesis of chronic periodontitis with diabetes mellitus was discussed to provide theory for orthodontic treatment.

\section{Materials and Methods}

Human osteoblast-like cells MG63 is provided by stomatology biology laboratory of Jilin University. MG63 were cultured in DMEM which contains $10 \%$ fetal bovine serum (FBS), $100 \mathrm{i} / \mathrm{ml}$ penicillin, and $100 \mathrm{ig} / \mathrm{ml}$ streptomycin at $37{ }^{\circ} \mathrm{C}$ and $5 \% \mathrm{CO}_{2}$. The medium contains $5.5,8,11,20$ and $30 \mathrm{mmol} / 1$ glucose was changed every two days. MG63 cells in the experimental group were cultured in different medium.

MTT assay [3-[4,5-dimethy 1thiazol-2-yl]-2,5diphenyltetrasodium bromide (MTT)] was used to estimate cell proliferation. MG63 cells were plated in 96 -well plates at a density of $1 \times 10^{3}$ cells/well and incubated at $37^{\circ} \mathrm{C}$ for 24 hours. Then the medium contained glucose was used. MG63 cells were cultured for 24 hours. $20 \mu \mathrm{l}$ MTT solution $(5 \mathrm{mg} / \mathrm{ml})$ was added to each 
J.Hard Tissue Biology Vol. 24(2):143 - 146, 2015

Table 1. The influence of glucose concentration on the cell proliferation of MG63 cells

\begin{tabular}{cccc}
\hline $\begin{array}{c}\text { Glucose } \\
(\mathrm{mmol} / \mathrm{l})\end{array}$ & $\mathrm{N}$ & $\begin{array}{c}\text { MTT } \\
\text { (A value) }\end{array}$ & $\begin{array}{c}\text { IR } \\
(\%)\end{array}$ \\
\hline 5.5 & 6 & $0.3138 \pm 0.0232$ & \\
8 & 6 & $0.3110 \pm 0.0334$ & 0.09 \\
11 & 6 & $0.2908 \pm 0.0120$ & 7.33 \\
20 & 6 & $0.2743 \pm 0.0137^{*}$ & 12.59 \\
30 & 6 & $0.2643 \pm 0.0054^{*}$ & 15.78 \\
\hline
\end{tabular}

$* \mathrm{p}<0.05$, compared with the results of $5.5 \mathrm{mmol} / \mathrm{l}$ group

well and cells were incubated at $37^{\circ} \mathrm{C}$ for 4 hours. The medium was removed and $150 \mu \mathrm{l}$ DMSO was added to each well. Absorbance (A) at $570 \mathrm{~nm}$ was detected. The average value was obtained to calculate growth inhibition. The cell growth inhibition rate was calculated as follows:

Cell growth inhibition rate $=\left(1-\mathrm{A}_{\text {test }} / \mathrm{A}_{\text {control }}\right) \times 100 \%$

MG63 cells were cultured with glucose medium. After 24 hours, cells were harvested and washed with PBS. Cells were suspended in $500 \mu \mathrm{l}$ of $70 \%$ alcohol and kept at $4{ }^{\circ} \mathrm{C}$ for 2 hours. Then cells were washed with PBS, treated with 100 il RNase A at $37^{\circ} \mathrm{C}$ for 30 minutes and stained with $400 \mu \mathrm{l}$ propidiun iodide at $4{ }^{\circ} \mathrm{C}$ for 30 minutes. DNA was analyzed by flow cytometry. Cell cycle and apoptosis was analyzed using Milti Cycle Software. Each experiment was performed in triplicate.

The expression levels of the genes OPG, OPGL, TRAIL and glyceraldehyde-3-phosphate dehydrogenase (GAPDH) were determined using RT-PCR. MG63 cells were seeded in 6-well plates. The total cellular RNA was extracted using TRIzol reagent in accordance with the manufacturer's instructions. GAPDH was used as an internal control. The primers used for PCR analysis were as follows: OPG forward, 5' AGTGGGAGCAGAAGACATTG-3'; reverse, 5' ATTGGACCTGGTTACCTATC-3'; OPGL forward, 5'GC G TCGCCC T G T T C T T TAT-3'; reverse, 5' TTGGTGCTTCCTCCTTTCAT-3'; TRAIL forward, 5'GGCATTCATTCCTGAGCAACTT-3'; reverse, 5' GATCTCGTGATCTACCCACCTT3-3'; GAPDH forward, 5'-
GAA GGTGAAGGTCGGAGTC-3' reverse, 5 ' GAAGATGGTGATGGGATTTC-3'.

Date was reported as means \pm standard deviations. LSD-t (least significant difference test) was used to compare means between two groups. One-way ANOVA was used to compare means of more than two groups. A value of $\mathrm{P}<0.05$ was considered to be statistically significant. All experiments were repeated for three times.

\section{Results}

MTT assay showed that MG63 cell proliferation was inhibited with the increase of glucose concentration as shown in Table 1. In comparison with the control group, a significant decrease in proliferation $(\mathrm{P}<0.05)$ was observed with glucose at concentration $20 \mathrm{mmol} / 1$ and $30 \mathrm{mmol} / \mathrm{l}$.

The cell cycle was evaluated by flow cytometry after the MG63 cells were exposed to glucose at various concentrations for 24 hours. As shown in Fig. 1 and Table 2, the cells in the G1 phase increased with the increase of glucose concentration. A reduction in the proportion of cells in G2 phase was observed. The results showed that glucose induced a cycle arrest in MG63 cell at G1 phase in a concentration-dependent manner. But there was no significant difference between $20 \mathrm{mmol} / 1$ and $30 \mathrm{mmol} / 1$ group, which showed that G1 phase inhibition was not obvious when the concentration of glucose reached a point.

RT-PCR results shown in Fig. 2 revealed that the OPG mRNA expression was down-regulated in the MG63 cell while the OPGL mRNA was up-regulated. And the TRAIL mRNA was also upregulated by glucose in a concentration-dependent manner.

\section{Discussion}

The in vitro experiments were carried out to evaluate the influence of glucose concentration on the proliferation, cell cycle and biomineralization of MG63 cell. Different glucose concentrations were selected in the experiments which were generally considered a normal serum glucose level or be near the level after meal. For example, a glucose concentration of $5.5 \mathrm{mmol} /$ 1 is equal to $99 \mathrm{mg} / \mathrm{dl}$, which is generally supposed to normal serum glucose levels before meal. A glucose concentration of 8 $\mathrm{mmol} / \mathrm{l}$ is equal to $144 \mathrm{mg} / \mathrm{dl}$, which is supposed to normal serum

Table 2. The effect of glucose on cell cycle distribution of MG63

\begin{tabular}{lcccc}
\hline $\begin{array}{l}\text { Glucose } \\
(\mathrm{mmol} / \mathrm{l})\end{array}$ & $\mathrm{n}$ & $\begin{array}{c}\text { G1 phase } \\
(\%)\end{array}$ & $\begin{array}{c}\text { S phase } \\
(\%)\end{array}$ & $\begin{array}{c}\text { G2 phase } \\
(\%)\end{array}$ \\
\hline $5.5 \mathrm{mmol} / 1$ & 3 & $40.9100 \pm 0.2945^{*}$ & $33.7967 \pm 0.9923$ & $25.2933 \pm 0.9511^{*}$ \\
$8 \mathrm{mmol} / 1$ & 3 & $49.1533 \pm 0.2279^{*}$ & $31.3167 \pm 0.6446$ & $19.5300 \pm 0.6417^{*}$ \\
$11 \mathrm{mmol} / 1$ & 3 & $52.2133 \pm 0.4792^{*}$ & $30.9233 \pm 0.1168$ & $16.8633 \pm 0.3934^{*}$ \\
$20 \mathrm{mmol} / 1$ & 3 & $56.2800 \pm 0.4330^{*}$ & $28.0700 \pm 0.6035^{*}$ & $15.6467 \pm 0.4054^{*}$ \\
$30 \mathrm{mmol} / 1$ & 3 & $57.2467 \pm 0.3093^{*}$ & $30.5200 \pm 0.2889^{*}$ & $12.2333 \pm 0.3375^{*}$ \\
\hline
\end{tabular}

${ }^{*} \mathrm{p}<0.05$, compared with the results of $5.5 \mathrm{mmol} / 1$ group 
Zhou Linxi et al.: Title: Effect of High Glucose on MG63 Osteoblasts
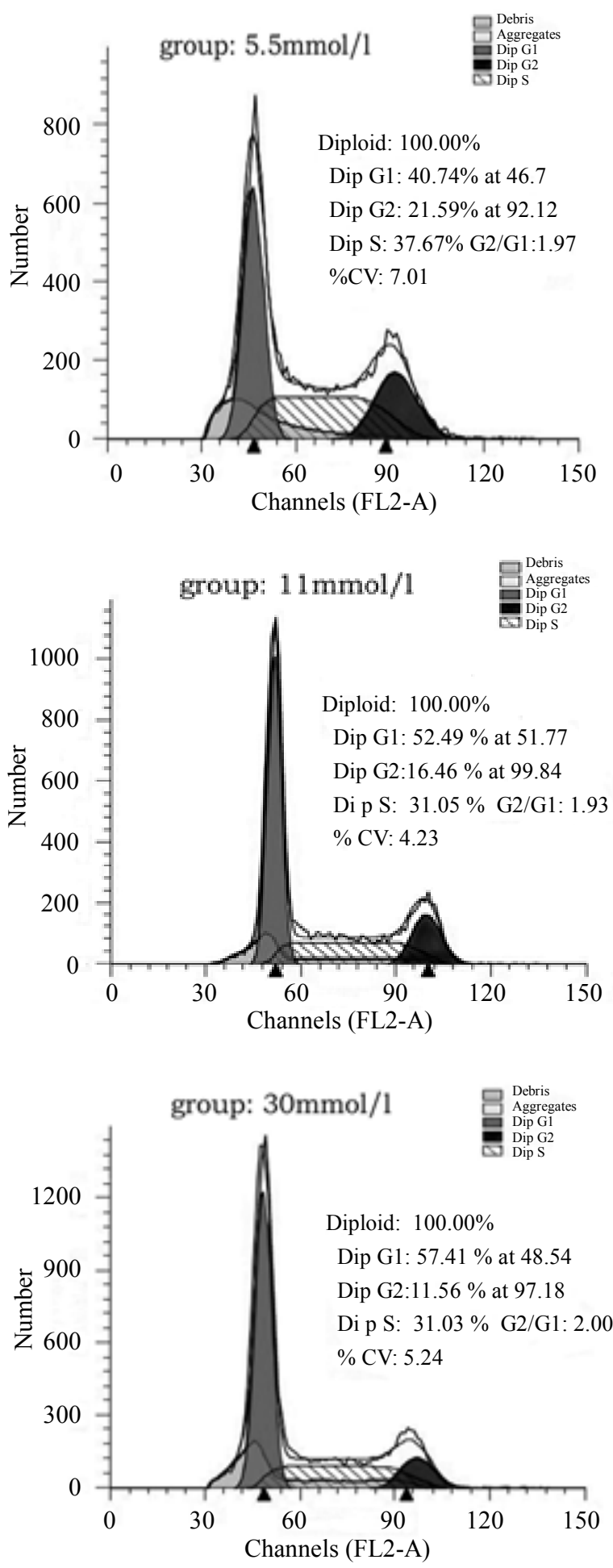

Figure 1. The results of flow cytometry for different glucose concentration.

glucose levels two hours after meal. A glucose concentration of $11 \mathrm{mmol} / 1$ is equal to $196 \mathrm{mg} / \mathrm{dl}$, which is supposed to serum glucose of uncontrolled diabetes mellitus. A glucose concentration of $20 \mathrm{mmol} / 1$ is equal to $360 \mathrm{mg} / \mathrm{dl}$, which is supposed to serum glucose of diabetes mellitus with bone complication. $30 \mathrm{mmol} / \mathrm{l}$
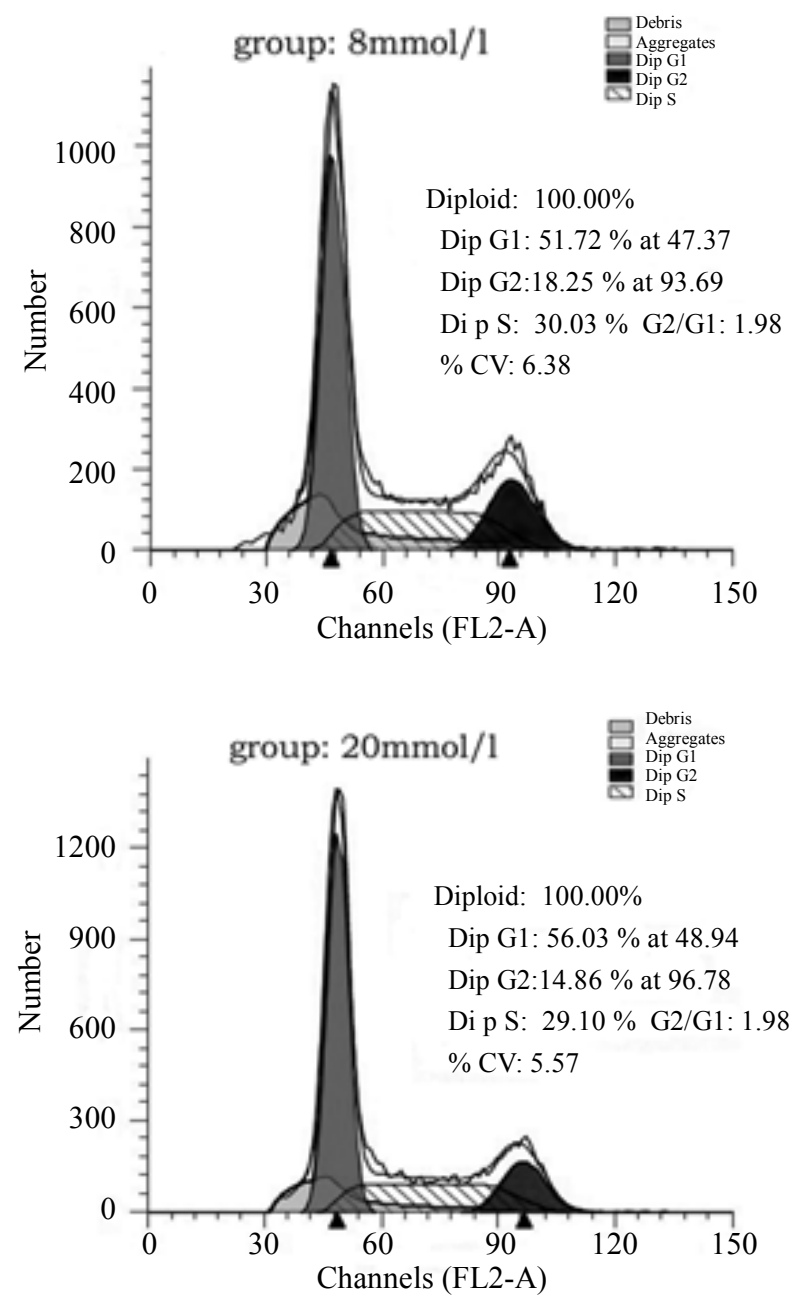

is considered to be high glucose media which is equal to $540 \mathrm{mg} /$ dl.

Because MG63 cells display all of the characteristics of osteoblast while offer the advantages of being a high-purity tumor cell line with unlimited growth capacity. The ell line is widely used as an osteoblast model for basic research and pharmacodynamics observation ${ }^{6}$. Cell cycle plays an important role in cell growth regulation. Extensive attention was paid to interfering the cell growth process by changing the cell cycle.

In cell cycle, G1 phase is the preparation for protein synthesis DNA replication and Histone Synthesis is in S phase. There are two restriction points for cell cycle, one is at the change for G1 to s phase. The other is at the change for G2 to M phase. When cell is injured, cell cycle is blocked. This is conducive to damage repair, which would keep genetic stability. When injury is too serious to be repaired, cells will apoptosis.

Diabetes mellitus may promote fibroblast and osteoblast cell apoptosis. Through the animal experiment, Liu et al. ${ }^{7)}$ found that apoptosis of osteoblasts and fibroblasts which were got from periodontal tissue of diabetic and periodontal rats increased. The number of osteoblasts decreased and bone formation reduced. 


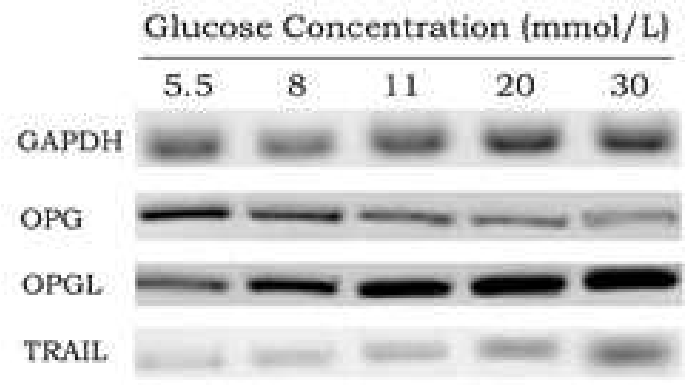

Figure 2. The influence of glucose concentration on TRAI, OPG and OPGL mRNA expression of MG63 cells.

inflammatory reaction of osteoblast. The current study yielded conflicting results about the effect by high serum glucose for biomineralization process of osteoblast. Weil et $\mathrm{al}^{1)}$ found that high serum glucose concentration won't affect cytokine production and diffusion of bone marrow mesenchymal stem cells. GarcíaHernández et al. ${ }^{16)}$ found that high serum glucose concentration could change osteoblast biomineralization process of human. These confliciting results may be caused by different cell lines, experimental conditions and glucose concentrations. The mechanism is still unknown and expected to be further studied.

\section{Acknowledgments}

This work was supported in part by Oral Biology Laboratory of Jilin University, Stomatology Hospital of Shenyang.

\section{References}

1. Weil BR, Abarbanell AM, Herrmann JL, Wang Y and Meldrum DR. High glucose concentration in cell culture medium does not acutely affect human mesenchymal stem cell growth factor production or proliferation. Am J Physiol Regul Integr Comp Physiol 296: 1735-1743, 2009

2. Li XJ, Li P and Zhang D. Diabetes mellitus related oral diseases. Med J of Peking Union Medical College Hosp 3: 232-235, 2012

3. Liu JQ, Liu HC, Wang Y, Feng Y and Gao H. The biological effect of high glucose on periodontal ligament cells. Shanghai J Stomatol 20: 225-229, 2011

4. Wittrant Y, Gorin Y, Woodruff K, Horn D, Abboud HE, Mohan S and Abboud SL. High D (+) glucose concentration inhibits RANKL-induced osteoclastogenesis. Bone 42: 1122-1130, 2008

5. Wang W, LiuY and Wang BK. The expression of RANKL and OPG mRNA of mice's alveolar bone under pressure. Beijing J Stomatol 17: 72-75, 2009
6. Bai XC, Lu D, Liu AL, Zhang ZM, Li XM, Zou ZP, Zeng WS, Cheng BL, and Luo SQ. Reactive oxygen species stimulates receptor activator of NF- kappaB ligand expression in osteoblast. Biol Chem 280: 17497-17506, 2005

7. Liu R, Bal HS, Desta T, Krothapalli N, Alyassi M, Luan Q and Graves DT. Diabetes enhances periodontal bone loss through enhanced resorption and diminished bone formation. Dent Res 85: 510-514, 2006

8. Al-Mashat HA, Kandru S, Liu R, Behl Y, Desta T and Graves DT. Diabetes enhances mRNA levels of proapoptotic genes and caspase activity, which contribute to impaired healing. Diabetes 55: 487-495, 2006

9. van den Oever IA, Raterman HG, Nurmohamed MT and Simsek S. Endothelial dysfunction, inflammation, and apoptosis in diabetes mellitus. Hindawi Publishing Corporation Mediators of Inflammation, Volume 2010, Article ID 792393, 15 pages, doi:10.1155/2010/792393

10. Wright HL, McCarthy HS, Middleton J and Marshall MJ. RANK, RANKL and osteoprotegerin in bone biology and disease. Curr Rev Musculoskelet Med 2: 56-64, 2009

11. Ogata N, Chikazu D, Kubota N, Terauchi Y, Tobe K, Azuma Y, Ohta T, Kadowaki T, Nakamura K, Kawaguchi H. Insulin receptor substrate-1 in osteoblast is indispensable for maintaining bone turnover. Clin Investm 105: 935-943, 2000

12. Botolin S and McCabe LR. Bone loss and increased bone adiposity in spontaneous and pharmacologically induced diabetic mice. Endocrinology 148: 198-205, 2007

13. Lam J, Nelson CA, Ross FP, Teitelbaum SL and Fremont DH. Crystal st ructure of the TRANCE/RANKL cytokine reveals determinant $\mathrm{s}$ of receptor-ligand specificity. Clin Invest 108: 971-979, 2001

14. Grimaud E, Redini F and Heymann D. Osteoprotegerin: a new agent for the treatment of bone disease. Drug Discov Today 6: 1241-1242, 2001

15. Fazzalari NL, Kuliwaba JS, Atkins GJ, Forwood MR and Findlay DM. The ratio of messenger RNA levels of receptor activator of nuclear factor kappaB ligand to osteoprotegerin correlates with bone remodeling indices in normal human cancellous bone but not in osteoarthritis. J Bone Miner Res 16: 1015-1027, 2001

16. García-Hernández A, Arzate H, Gil-Chavarria 1, Rojo R and Moreno-Fierros L. High glucose concentrations alter the biomineralization process in human osteoblastic cells. Bone 50: 276-288, 2012 